\title{
PERBAIKAN SIFAT KIMIA TANAH DENGAN APLIKASI KOMPOS ALANG - ALANG PADA GAMBUT TERBAKAR DAN PENGARUHNYA TERHADAP PERTUMBUHAN DAN PRODUKSI KACANG HIJAU (Vigna radiata L.)
}

\author{
The Improvement of Soil Chemical Properties with Application of Alang - Alang Compost \\ on Burned Peatland and Their Effect on The Growth and Production of Mung Bean \\ (Vigna radiata $\mathbf{L}$.)
}

\author{
Tati Maharani \\ Jurusan Agroteknologi, Fakultas Pertanian, Universitas Islam Riau \\ Email: tatimaharani@agr.uir.ac.id/요 $\underline{11752604}$ \\ [Diterima: Juli 2021; Disetujui: Agustus 2021]
}

\begin{abstract}
This research aimed to determine the effect of alang-alang compost application on burned peatland to cultivate the soil chemical properties, growth, and production of mung beans (Vigna radiata L.). The research has been carried out in the Auto Agronom of the Faculty of Agriculture, Universitas Islam Riau from October 2018 to April 2019. The design in this study was a Factorial Completely Randomized Design (CRD) consisting of 2 factors, G (burned peatland) and P (alang-alang compost application). The results showed that the application of alang-alang compost toward burned peatland was able to cultivate the soil's chemical properties in the form of increasing $\mathrm{pH}$, C-organic, N-total, P2O5, K-dd, Mg-dd, Ca-dd, KTK, and reducing C/N Ratio, Al-dd, Total Pb. The best results were obtained by applying alang-alang compost $375 \mathrm{~g} /$ polybag compost on burned peatland at the depth of $0-25 \mathrm{~cm}$. The treatment interaction of burned peatland and alang-alang compost has a significant effect on the parameters of Plant Height and Dry Weight of Seeds per Plant, with the best treatment application of alang-alang compost $375 \mathrm{~g} /$ polybag on burned peatland at the depth of $25-50 \mathrm{~cm}$. The main influences of alang-alang compost application have a significant influence on Plant Height and Dry Weight of Seeds per Plant, the best treatment was the application of alang-alang compost $375 \mathrm{~g} /$ polybag.
\end{abstract}

Keywords: Alang-alang compost, Burned peatland, Mung beans

\begin{abstract}
ABSTRAK
Penelitian ini bertujuan untuk mengetahui pengaruh aplikasi kompos alang-alang pada tanah gambut terbakar terhadap perbaikan sifat kimia tanah, pertumbuhan dan produksi Kacang Hijau (Vigna radiata L.). Telah dilaksanakan di Auto Agronom Fakultas Pertanian Universitas Islam Riau mulai bulan Oktober 2018 sampai bulan April 2019. Rancangan yang digunakan pada penelitian ini adalah Rancangan Acak Lengkap (RAL) Faktorial yang terdiri dari 2 faktor yaitu G (tanah gambut terbakar) dan K (aplikasi kompos alang- alang). Hasil penelitian menunjukkan bahwa aplikasi kompos alang-alang pada tanah gambut terbakar mampu memperbaiki sifat kimia tanah berupa peningkatan pH, C-organik, N-total, P2O5, K-dd, Mg-dd, Ca-dd, KTK dan menurunkan C/N Ratio, Al-dd, Total $\mathrm{Pb}$. Hasil terbaik diperoleh dengan mengaplikasikan kompos alang-alang $375 \mathrm{~g} /$ polybag pada tanah gambut terbakar kedalaman 0-25 cm. Interaksi Perlakuan tanah gambut terbakar dan aplikasi kompos alang-alang memberikan pengaruh nyata terhadap parameter Tinggi Tanaman dan Berat Kering Biji per Tanaman, dengan perlakuan terbaik aplikasi kompos alang-alang $375 \mathrm{~g} /$ polybag pada tanah gambut terbakar kedalaman $25-50 \mathrm{~cm}$. Pengaruh utama aplikasi kompos alang-alang memberikan pengaruh nyata terhadap Tinggi Tanaman dan Berat Kering Biji per Tanaman, perlakuan terbaik adalah aplikasi kompos alang-alang $375 \mathrm{~g} /$ polybag.
\end{abstract}

Kata kunci: Kompos alang - alang, Tanah gambut terbakar, Kacang hijau 


\section{PENDAHULUAN}

Bagi masyarakat Indonesia tanaman Kacang Hijau (Vigna radiata L.) merupakan tanaman sumber protein setelah kedelai dan kacang tanah. Produksi kacang hijau nasional mencapai 234.718 ton dengan luas panen 197.508 ha. Produktivitas kacang hijau pada lahan pertanian di Indonesia adalah 11.30 $\mathrm{ku} / \mathrm{ha}$ pada tahun 2016, $11.69 \mathrm{ku} / \mathrm{ha}$ pada tahun 2017 dan $11.88 \mathrm{ku} / \mathrm{ha}$ di tahun 2018. Pada tahun 2015, 2016, 2017 dan 2018 Indonesia masih mengimpor kacang hijau masing masing sebesar 45.213 ton, 64.735 ton, 78.786 ton dan 92.226 ton (Kementerian Pertanian Republik Indonesia, 2019).

Usaha untuk meningkatkan produksi kacang hijau nasional perlu dilakukan baik secara intensifikasi maupun ekstensifikasi. Upaya ekstensifikasi yaitu perluasan pertanaman dengan cara memanfaatkan lahan - lahan bermasalah (marginal) merupakan alternatif yang dapat dilakukan untuk meningkatkan produksi tanaman kacang hijau. Perluasan pertanaman tersebut dapat dilakukan baik pada lahan basah maupun lahan kering seperti lahan gambut.

Potensi lahan gambut di Indonesia cukup luas untuk dijadikan areal ekstensifikasi pertanian. Wahyunto dan Heryanto (2005) menyatakan Provinsi Riau memiliki lahan gambut terluas di Sumatera, yakni mencapai $56.1 \%$. Pengembangan lahan gambut sebagai lahan pertanian terdapat berbagai kendala baik fisik, kimia maupun biologis. Menurut Anshari (2010), kesesuaian lahan untuk pertanian menurun pada lahan gambut yang terdegradasi. Dikici dan Yilmaz (2006) menyatakan degradasi lahan gambut dapat disebabkan oleh pengelolaan lahan yang tidak tepat antara lain pembukaan lahan, pembuatan saluran drainase, kebakaran atau pembakaran lahan gambut.

Menurut Lubis (2016) dampak negatif kebakaran mengakibatkan kerusakan pada karakteristik fisik, kimia, dan biologi tanah gambut. Selanjutnya menurut Rauf dan Fauzi (2013) dalam Mintari et al. (2019), dampak kebakaran lahan, termasuk pada lahan gambut, bisa berpengaruh pada dua sisi yaitu dampak on site (pada lahannya) dan dampak off site (di luar sistem lahannya). Dampak on site meliputi peningkatan $\mathrm{pH}$ tanah, peningkatan garamgaram mudah larut (basa-basa tukar), yang mendorong peningkatan kejenuhan basa.
Pengaplikasian amelioran diharapkan mampu memperbaiki sifat kimia tanah gambut yang terbakar. Amelioran merupakan bahan yang ditambahkan ke dalam tanah untuk memperbaiki lingkungan akar bagi pertumbuhan tanaman. Menurut Arief dan Irman (1996), dua bahan yang sudah dikenal luas untuk ameliorasi lahan masam adalah kapur dan bahan organik.

Pembuatan kompos merupakan suatu cara yang efektif dalam penggunaan bahan organik, karena pemberian bahan organik dalam bentuk segar ke dalam tanah dapat menyebabkan immobilisasi $\mathrm{N}$ di dalam tanah, dengan penggunaan kompos yang bekelanjutan, maka bahan organik tanah dapat ditingkatkan dalam sifat fisika, kimia dan biologi tanah dapat diperbaiki.

Komposisi kimia dari kompos bervariasi tergantung jenis bahan dan proses pembuatannya, dalam penelitian ini dicobakan alang - alang (Imperata cylindrica (L.) Beauv) sebagai bahan kompos, serta ketersediaannya banyak untuk dimanfaatkan dan sejauh ini kerugian yang ditimbulkan alang - alang jauh lebih besar dari manfaat yang diperoleh dan dimasukkan kategori atau prioritas utama gulma yang harus dikendalikan atau diberantas serta usaha - usaha untuk memanfaatkannya serta dicari dan diteliti.

Berdasarkan permasalahan di atas, telah dilakukan penelitian mengenai "Perbaikan Sifat Kimia Tanah dengan Aplikasi Kompos Alang - Alang pada Gambut Terbakar dan Pengaruhnya Terhadap Pertumbuhan dan Produksi Kacang Hijau (Vigna radiata L.)", sehingga pengelolaan lahan gambut terbakar sebagai lahan budidaya tanaman kacangkacangan diharapkan menjadi lebih efektif, efisien dan berkelanjutan.

\section{METODE PENELITIAN}

Penelitian dilaksanakan di Auto Agronom Fakultas Pertanian Universitas Islam Riau, Jalan Kaharuddin Nasution No. 113 Kelurahan Air Dingin, Kecamatan Bukit Raya, Kota Pekanbaru. Pengukuran parameter tanaman dan analisis sifat kimia tanah dilakukan di Laboratorium Bioteknologi Fakultas Pertanian Universitas Islam Riau dan Laboratorium Central Plantation Services PT. Central Alam Resources Lestari, Jalan H. R. Soebrantas No. 134 Panam Pekanbaru. 
Kegiatan penelitian dilaksanakan selama 6 (enam) bulan, dimulai dari bulan Oktober 2018 - April 2019.

Bahan yang digunakan dalam penelitian ini meliputi tanah gambut terbakar, daun alang - alang segar, pupuk Urea, pupuk TSP, pupuk $\mathrm{KCl}$, pupuk kandang ayam, benih kacang hijau varietas kutilang, kapur Dolomit, Dithane - 45 WP, Decis, cat minyak.

Tanah gambut terbakar diambil pada lahan gambut yang berlokasi di Jalan Pekanbaru - Bangkinang Dusun III Desa Rimbo Panjang Kecamatan Tambang Kabupaten Kampar, Provinsi Riau. Lokasi pengambilan tanah ini merupakan lahan gambut bekas terbakar pada tahun 2015. Lahan tersebut didominasi oleh lahan gambut dengan tingkat kematangan antara saprik dan hemik serta memiliki kedalaman 4-7 meter.

Peralatan yang digunakan antara lain bak pengomposan, cangkul, parang, sekop, timbangan, meteran, $\mathrm{pH}$ meter, plat perlakuan, paku, handsprayer, polybag $35 \times 40 \mathrm{~cm}$, gembor, ember, gelas ukur, goni, kamera digital serta alat-alat tulis.

Rancangan yang digunakan dalam penelitian ini adalah Rancangan Acak Lengkap (RAL) Faktorial yang terdiri dari 2 faktor yaitu $\mathrm{G}$ (tanah gambut terbakar) dan K (aplikasi kompos alang-alang), dan data hasil pengamatan dari masing - masing perlakuan kemudian dianalisis secara statistik, apabila Fhitung lebih besar dari Ftabel maka dilanjutkan dengan uji lanjut BNJ (Beda Nyata Jujur) $5 \%$.

\section{HASIL DAN PEMBAHASAN}

\section{Sifat Kimia Tanah Gambut Tidak Terbakar dan Terbakar pada Kedalaman $0-25 \mathrm{~cm}$, $25-50 \mathrm{~cm}$ dan $50-75 \mathrm{~cm}$.}

Hasil analisis sifat kimia terhadap tanah gambut tidak terbakar dan terbakar pada kedalaman $0-25 \mathrm{~cm}, 25-50 \mathrm{~cm}$ dan $50-75$ cm disajikan pada Tabel 1 .

Tabel 1. Hasil Analisis Sifat Kimia Tanah Gambut Tidak Terbakar dan Terbakar

\begin{tabular}{|c|c|c|c|c|c|c|c|}
\hline \multirow{3}{*}{$\begin{array}{l}\text { Sifat Kimia } \\
\text { Tanah }\end{array}$} & \multirow{3}{*}{$\begin{array}{c}\text { Satuan } \\
\text { Unit }\end{array}$} & \multicolumn{6}{|c|}{ Kedalaman $(\mathrm{cm})$} \\
\hline & & \multicolumn{3}{|c|}{ Tidak Terbakar } & \multicolumn{3}{|c|}{ Terbakar } \\
\hline & & $0-25$ & $25-50$ & $50-75$ & $0-25$ & $25-50$ & $50-75$ \\
\hline $\mathrm{pH}(\mathrm{H} 2 \mathrm{O})$ & & 5.05 & 5.39 & 5.53 & 3.44 & 3.23 & 3.46 \\
\hline C-Organik & $\%$ & 48.3 & 36.4 & 34.2 & 54.7 & 54.2 & 55.3 \\
\hline N Total & $\%$ & 0.74 & 0.84 & 0.72 & 1.01 & 0.84 & 0.68 \\
\hline C/N Ratio & & 65.3 & 43.3 & 47.5 & 54.2 & 64.5 & 81.3 \\
\hline P2O5 (Bray 2) & ppm & 95.9 & 124.5 & 164.9 & 67.3 & 186.0 & 84.1 \\
\hline Al-dd & $\mathrm{cmol} / \mathrm{kg}$ & 0.40 & 0.60 & 0.60 & 1.70 & 1.80 & 1.60 \\
\hline K-dd & $\mathrm{cmol} / \mathrm{kg}$ & 0.50 & 0.76 & 2.56 & 0.55 & 0.91 & 0.57 \\
\hline Mg-dd & $\mathrm{cmol} / \mathrm{kg}$ & 2.64 & 2.22 & 1.77 & 1.05 & 1.85 & 1.77 \\
\hline Ca-dd & $\mathrm{cmol} / \mathrm{kg}$ & 39.4 & 35.3 & 28.0 & 1.44 & 2.68 & 2.49 \\
\hline CEC (KTK) & $\mathrm{cmol} / \mathrm{kg}$ & 41.47 & 36.59 & 29.90 & 54.23 & 57.50 & 57.43 \\
\hline Total $\mathrm{Pb}$ & ppm & 4.00 & 4.40 & 4.20 & 4.80 & 4.70 & 5.20 \\
\hline Total Cd & ppm & $<0.20$ & $<0.20$ & $<0.20$ & $<0.20$ & $<0.20$ & $<0.20$ \\
\hline
\end{tabular}

Sumber: Laboratorium Central Plantation Services PT. Central Alam Resources Lestari, tanggal 09 Februari 2019

Tabel 1 menunjukkan bahwa $\mathrm{pH}$ (H2O) tanah gambut tidak terbakar pada tiga kedalaman tergolong rendah dan masam yaitu 5.05, 5.39 dan 5.53. Kandungan C-Organik pada tanah gambut tidak terbakar pada tiga kedalaman masing - masingnya $48.3 \%, 36.4$ $\%$ dan $34.2 \%$ termasuk dalam kategori tinggi. Adapun $\mathrm{N}$ total yang diperoleh dari hasil pengujian tanah gambut tidak terbakar pada ketiga kedalaman adalah $0.74 \%, 0.84 \%$ dan $0.72 \%$ termasuk kategori tinggi.
Rasio C/N tanah gambut umumnya (25 - 35). Hasil pengujian pada Tabel 1 di atas menunjukkan Rasio $\mathrm{C} / \mathrm{N}$ tanah gambut tidak terbakar untuk masing-masing kedalaman adalah 65.3, 43.3 dan 65.3. Rasio $\mathrm{C} / \mathrm{N}$ tertinggi diperoleh dari kedalam gambut $0-25 \mathrm{~cm}$, hal ini menunjukkan bahwa perombakan bahan organik belum sempurna sehingga terjadi immobilisasi N. Perombakan dikatakan sempurna jika nisbah $\mathrm{C} / \mathrm{N}$ kecil dari 20 (Murayama dan Abu bakar, 1996) dalam (Riadi et al., 2015). 
Kandungan unsur hara P2O5 tanah gambut tidak terbakar pada tiap kedalaman masing-masing adalah 95.9 ppm (0.00959\%), $124.5 \mathrm{ppm}(0.01245 \%)$ dan $164.9 \mathrm{ppm}$ $(0.01649 \%)$, hal ini menunjukkan keberadaan unsur hara $\mathrm{P}$ tersedia pada tanah gambut tidak terbakar. Rendahnya ketersediaan unsur $\mathrm{P}$ tersebut salah satunya diduga karena $\mathrm{pH}$ tanah gambut yang masam. Parameter uji kemasaman dapat ditukar (Al-dd) tanah gambut tidak terbakar pada tiap kedalaman masing-masing adalah $0.40 \mathrm{cmol} / \mathrm{kg}, \quad 0.60$ $\mathrm{cmol} / \mathrm{kg}$ dan $0.60 \mathrm{cmol} / \mathrm{kg}$ yang menurut Panduan Kriteria Penilaian Sifat - Sifat Tanah yang diterbitkan oleh Balai Penelitian Tanah Bogor (2009) termasuk kriteria sangat rendah yaitu $<15 \mathrm{me} / 100 \mathrm{~g}$ tanah atau sama dengan < $15 \mathrm{cmol} / \mathrm{kg}$ tanah.

Kandungan basa - basa pada tanah gambut terbakar untuk kedalaman $0-25 \mathrm{~cm}$, $25-50 \mathrm{~cm}$ dan $50-75 \mathrm{~cm}$ yaitu K-dd dengan nilai $0.50 \mathrm{cmol} / \mathrm{kg} ; 0.76 \mathrm{cmol} / \mathrm{kg} ; 2.56 \mathrm{cmol} / \mathrm{kg}$ menunjukkan kriteria Sedang - Tinggi Sangat Tinggi, Mg-dd dengan nilai 2.64 $\mathrm{cmol} / \mathrm{kg} ; \quad 2.22 \mathrm{cmol} / \mathrm{kg} ; \quad 1.77 \mathrm{cmol} / \mathrm{kg}$ menunjukkan kriteria Tinggi - Tinggi Sedang, dan Ca-dd dengan nilai $39.4 \mathrm{cmol} / \mathrm{kg}$; $35.3 \mathrm{cmol} / \mathrm{kg} ; \quad 28.0 \mathrm{cmol} / \mathrm{kg}$ seluruhnya menunjukkan kriteria sangat tinggi yaitu $>20$.

Nilai Kapasitas Tukar Kation (KTK) tanah gambut tidak terbakar yang telah dianalisis pada kedalaman $25-50 \mathrm{~cm}$ dan $50-$ $75 \mathrm{~cm}$ tergolong tinggi berada pada rentang nilai $25-40 \mathrm{cmol} / \mathrm{kg}$. Berdasarkan hasil analisa yang diperoleh tanah gambut tidak terbakar pada kedalaman $0-25 \mathrm{~cm}, 25-50$ $\mathrm{cm}$ dan $50-75 \mathrm{~cm}$ yang digunakan pada penelitian ini memiliki kadar logam berat $\mathrm{Pb}$ total masih berada pada batas normal logam berat $\mathrm{Pb}$ di dalam tanah. Kadar timbal yang terdapat di dalam tanah gambut dikatakan telah melebihi batas kritis logam berat $\mathrm{Pb}$ dalam tanah sebagaimana yang ditetapkan oleh Ministry of State for Population and Enviromental of Indonesia and Dalhousie University Canada (1992) adalah $100 \mathrm{mg} / \mathrm{kg}$.

Hasil pengujian kadar logam berat Kadmium (Cd) pada tanah gambut tidak terbakar untuk kedalaman $0-25 \mathrm{~cm}, 25-50$ $\mathrm{cm}$ dan $50-75 \mathrm{~cm}$, menunjukkan hasil yang sama yaitu < 20 ppm, kadar $\mathrm{Cd}$ ini masih berada pada batas normal logam berat $\mathrm{Cd}$ di dalam tanah.

Dari Tabel 1 dapat diketahui bahwa kadar karbon (C) organik pada tanah gambut terbakar kedalaman $0-25 \mathrm{~cm}, 25-50 \mathrm{~cm}$ dan $50-75 \mathrm{~cm}$ justru lebih tinggi dibandingkan pada tanah gambut yang tidak terbakar pada kedalaman yang sama. Seperti halnya pada rataan kadar C-organik dan $\mathrm{N}$-total, ratio $\mathrm{C} / \mathrm{N}$ juga lebih tinggi pada lahan gambut yang terbakar kedalaman $25-50 \mathrm{~cm}$ dan $50-75 \mathrm{~cm}$ yaitu 64.5 dan 81.3 kecuali pada kedalam $0-$ $25 \mathrm{~cm}$ lebih rendah jika dibandingkan pada tanah gambut tidak terbakar yaitu 54.2. Adapun $\mathrm{pH}$ tanah gambut terbakar pada kedalaman $0-25 \mathrm{~cm}, 25-50 \mathrm{~cm}$ dan $50-75$ $\mathrm{cm}$ yaitu 3.44, 3.23 dan 3.46 justru lebih rendah atau tergolong Sangat Masam bila ditinjau dari kriteria sifat kimia tanah yang dikeluarkan oleh Balai Penelitian Tanah Bogor (2009), sementara pada tanah gambut yang tidak terbakar kedalaman $0-25 \mathrm{~cm}, 25-50$ $\mathrm{cm}$ dan $50-75 \mathrm{~cm}$ memiliki $\mathrm{pH}$ yang lebih tinggi (tergolong masam dan agak masam berdasarkan kriteria sifat kimia tanah yang dikeluarkan oleh Balai Penelitian Tanah Bogor, 2009) yaitu 5.05, 5.39 dan 5.53. Berdasarkan hasil analisis pada Tabel 1, sifat dan ciri tanah gambut di lokasi penelitian (Desa Rimbo Panjang Kecamatan Tambang) memiliki pH rendah yakni 3.23 - 3.46 dan tergolong kedalam kriteria sangat masam.

Bila ditinjau dari kriteria sifat kimia tanah yang dikeluarkan oleh Balai Penelitian Tanah Bogor (2009) kadar P-tersedia pada semua kedalaman tanah gambut (G1, G2 dan G3) di Desa Rimbo Panjang Kecamatan Tambang tergolong Sangat Tinggi, dan nilai K-dd pada semua kedalaman tanah gambut (G1, G2 dan G3) di Desa Rimbo Panjang Kecamatan Tambang termasuk kriteria Sedang, Tinggi, dan Sangat Tinggi. Kadar basa tukar lainnya menurut kriteria sifat kimia tanah yang dikeluarkan oleh Balai Penelitian Tanah Bogor (2009), meliputi Mg-dd dan Ca-dd (Tabel 1) pada tanah gambut tidak terbakar pada kedalaman $0-25 \mathrm{~cm}, 25-50 \mathrm{~cm}$ dan 50 - $75 \mathrm{~cm}$ lebih tinggi dibandingkan dengan tanah gambut terbakar pada kedalaman yang sama.

Kebakaran lahan gambut di Desa Rimbo Panjang Kecamatan Tambang tidak berpengaruh pada peningkatan kadar elemen $\mathrm{Pb}$ dan $\mathrm{Cd}$ di dalam tanah gambut serta tidak atau belum menyebabkan terjadinya pencemaran lingkungan. Hasil pengujian memperlihatkan bahwa Al-dd mengalami peningkatan pada tanah gambut terbakar pada 
kedalaman $0-25 \mathrm{~cm}, 25-50 \mathrm{~cm}$ dan $50-75$ cm (Tabel 1).

Hasil analisis sampel tanah gambut terbakar sebelum diberi perlakuan kompos alang - alang pada masing - masing kedalaman yang dilakukan di laboratorium menunjukkan bahwa kandungan KTK tergolong sangat tinggi yaitu $>40 \mathrm{me} / 100 \mathrm{~g}$ atau $>40 \mathrm{cmol} / \mathrm{kg}$ yaitu $54.23 \mathrm{cmol} / \mathrm{kg}, 57.50$ $\mathrm{cmol} / \mathrm{kg}$ dan $57.43 \mathrm{cmol} / \mathrm{kg}$, menurut Mukhlis (2011) dalam Mintari et al. (2019) hal ini disebabkan karena perubahan KTK tergantung pada itensitas kebakaran yang terjadi, tekstur tanah dan persediaan bahan organik di tanah.

\section{Komposisi dan Kandungan Hara Kompos Alang-Alang}

Kompos yang telah matang dan dihaluskan, selanjutnya dilakukan pengujian di laboratorium untuk mengetahui komposisi dan kandungan haranya. Hasil analisis kimia terhadap komposisi dan kandungan hara kompos alang-alang disajikan pada Tabel 2.

Tabel 2. Hasil Analisis Kimia Kompos Alang-Alang

\begin{tabular}{lccc}
\hline \multicolumn{1}{c}{ Parameter } & Nilai & Satuan Unit & Metode Analisis \\
\hline Total $\mathrm{N}$ & 2.01 & $\%$ & IKP-16 (Kjeldahl) \\
Total P2O5 & 2.40 & $\%$ & IKP-16 (Spectrophotometry) \\
Total K2O & 1.25 & $\%$ & IKP-16 (Spectrophotometry) \\
Total $\mathrm{Mg}$ & 1.51 & $\%$ & IKP-16 (AAS) \\
Total $\mathrm{Ca}$ & 4.58 & $\%$ & IKP-16 (AAS) \\
Total Pb & 9.92 & $\mathrm{mg} / \mathrm{kg}$ & IKP-16 (AAS) \\
Total Cd & 0.62 & $\mathrm{mg} / \mathrm{kg}$ & IKP-16 (AAS) \\
Al-dd & 0.50 & $\mathrm{cmol} / \mathrm{kg}$ & IKP-16 (Titrimetry) \\
KTK & 19.93 & $\mathrm{cmol} / \mathrm{kg}$ & IKP-16 (Titrimetry) \\
C-Organik & 30.5 & $\%$ & IKP-16 (Loss on Ignition) \\
Rasio C/N & 15.2 & - & Calculation \\
pH (H2O) & 6.90 & - & IKP-16 (pH Meter) \\
\hline
\end{tabular}

Sumber: Laboratorium Central Plantation Services PT. Central Alam Resources Lestari, tanggal 29 Januari 2019

Kompos alang-alang menghasilkan kandungan unsur hara lebih tinggi jika dibandingkan dengan kompos TKS. Hasil Penelitian Yunindanova et al. (2013) dalam Sutriana dan Baharuddin, (2017).menunjukkan bahwa kandungan $\mathrm{N}$ total yang dihasilkan TKS yaitu di atas $1 \%$, namun kandungan $\mathrm{P}$ yang lebih rendah yaitu hanya berkisar di bawah 0.1 $\%$. Hal ini memperlihatkan bahwa kompos alang-alang yang digunakan cukup potensial karena memiliki kandungan hara tinggi.

Sifat Kimia Tanah Gambut Terbakar pada Kedalaman 0 - $25 \mathrm{~cm}, 25-50 \mathrm{~cm}, 50$ - 75 cm Setelah Aplikasi Perlakuan

Hasil pengujian sifat kimia terhadap tanah gambut terbakar pada kedalaman $0-25$ $\mathrm{cm}, 25-50 \mathrm{~cm}$ dan $50-75 \mathrm{~cm}$ setelah aplikasi perlakuan kompos alang - alang disajikan pada Tabel 3.

Nilai $\mathrm{pH}$ tanah gambut terbakar pada kedalaman $0-25 \mathrm{~cm}, 25-50 \mathrm{~cm}$ dan $50-75$ $\mathrm{cm}$ sebelum aplikasi perlakuan menunjukkan peningkatan setelah diberikan perlakuan kompos alang-alang, walaupun nilai tersebut masih termasuk kriteria sangat masam.
Peningkatan $\mathrm{pH}$ tanah gambut terbakar setelah aplikasi perlakuan, nilai tertinggi diperoleh pada kedalaman gambut $0-25 \mathrm{~cm}$ (G1) dengan kompos alang-alang $250 \mathrm{~g} /$ polybag (K2) yaitu 4.46 sedangkan penambahan $\mathrm{pH}$ yang terkecil diperoleh pada kedalaman gambut $25-50 \mathrm{~cm}(\mathrm{G} 2)$ dan diberikan kompos alang-alang $125 \mathrm{~g} /$ polybag (K1). Menurut Stevenson (1982) dan Hesse (1984) dalam Maharani (2002), meningkatnya $\mathrm{pH}$ tanah antara lain karena bahan organik dari kompos dapat menetralisir kemasaman tanah dan juga karena bahan organik dari kompos dapat mengkompleks aluminium yang terlarut sehingga mengurangi kelarutannya dan menyumbangkan ion $\mathrm{OH}$ yang dapat meningkatkan $\mathrm{pH}$, selanjutnya Hoyt dan Turner (1975) dalam Maharani (2002) juga melaporkan bahwa pemberian bahan organik berupa kompos dalam jumlah besar pada tanah masam dapat meningkatkan $\mathrm{pH}$ tanah.

Hasil pengujian tanah juga menunjukkan beberapa tanah gambut terbakar dengan aplikasi perlakuan kompos alang-alang pada masing - masing kedalaman yang 
mengalami peningkatan Al-dd. Secara umum Al-dd tanah gambut terbakar pada kedalaman 0 $-25 \mathrm{~cm}, 25-50 \mathrm{~cm}$ dan $50-75 \mathrm{~cm}$ sebelum dan sesudah aplikasi perlakuan kompos alang alang memiliki Al-dd yang sangat rendah.

Tabel 3. Hasil Analisis Sifat Kimia Tanah Gambut Terbakar Setelah Aplikasi Perlakuan

\begin{tabular}{|c|c|c|c|c|c|c|c|c|c|c|c|c|c|}
\hline \multirow{4}{*}{$\begin{array}{l}\text { Sifat Kimia } \\
\text { Tanah }\end{array}$} & \multirow{4}{*}{$\begin{array}{l}\text { Satuan } \\
\text { Unit }\end{array}$} & \multicolumn{12}{|c|}{ Tanah Gambut Terbakar } \\
\hline & & \multirow{2}{*}{\multicolumn{4}{|c|}{$\mathrm{G}_{!}($kedalaman $0-25 \mathrm{~cm})$}} & \multicolumn{4}{|c|}{$\mathrm{G}_{2}($ kedalaman $25-50 \mathrm{~cm})$} & \multicolumn{4}{|c|}{$\mathrm{G}_{3}($ kedalaman $50-75 \mathrm{~cm})$} \\
\hline & & & & & & \multicolumn{8}{|c|}{ Aplikasi Kompos Alang - Alang ( $/$ /polybag) } \\
\hline & & $\mathrm{K}_{0}(0)$ & $\begin{array}{c}\mathrm{K}_{\mathrm{I}} \\
(125)\end{array}$ & $\begin{array}{c}\mathrm{K}_{2} \\
(250)\end{array}$ & $\begin{array}{c}\mathrm{K}_{3} \\
(375)\end{array}$ & $\mathrm{K}_{0}(0)$ & $\begin{array}{c}\mathrm{K}_{\mathrm{I}} \\
(125)\end{array}$ & $\begin{array}{c}\mathrm{K}_{2} \\
(250)\end{array}$ & $\begin{array}{c}\mathrm{K}_{3} \\
(375)\end{array}$ & $\mathrm{K}_{\circ}(0)$ & $\underset{(125)}{\mathrm{K}_{\mathrm{I}}}$ & $\begin{array}{c}\mathrm{K}_{2} \\
(250)\end{array}$ & $\begin{array}{c}\mathrm{K}_{3} \\
(375)\end{array}$ \\
\hline $\mathrm{pH}(\mathrm{H} 2 \mathrm{O})$ & - & 4.41 & 4.01 & 4.46 & 4.21 & 4.37 & 3.97 & 4.13 & 4.41 & 3.91 & 4.10 & 4.14 & 4.05 \\
\hline C-Organik & $\%$ & 53.40 & 54.10 & 51.20 & 50.40 & 54.80 & 54.30 & 50.90 & 52.50 & 55.4 & 54.70 & 53.30 & 52.50 \\
\hline N Total & $\%$ & 0.90 & 0.96 & 0.93 & 1.04 & 0.79 & 0.70 & 0.91 & 0.83 & 0.62 & 0.60 & 0.61 & 0.69 \\
\hline C/N Ratio & - & 59.30 & 56.400 & 55.10 & 48.50 & 69.40 & 77.60 & 55.90 & 63.30 & 89.4 & 91.20 & 87.40 & 76.10 \\
\hline P205 (Brav 2) & $\mathrm{ppm}$ & 53.10 & 345.40 & 804.80 & 911.80 & 38.70 & 273.20 & 845.60 & 935.60 & 55.7 & 319.90 & 551.10 & 195.90 \\
\hline Al-dd & $\mathrm{cmol} / \mathrm{kg}$ & 1.00 & 2.00 & 1.80 & 1.60 & 1.40 & 1.60 & 2.80 & 3.60 & 2.40 & 1.60 & 1.60 & 1.40 \\
\hline K-dd & $\mathrm{cmol} / \mathrm{kg}$ & 0.70 & 1.13 & 3.15 & 2.75 & 0.81 & 1.04 & 2.67 & 2.22 & 0.41 & 0.95 & 1.46 & 2.02 \\
\hline Mg-dd & $\mathrm{cmol} / \mathrm{kg}$ & 1.52 & 2.56 & 3.50 & 3.40 & 1.41 & 2.45 & 3.53 & 3.46 & 1.28 & 2.15 & 2.86 & 3.18 \\
\hline Ca-dd & $\mathrm{cmol} / \mathrm{kg}$ & 16.62 & 9.18 & 19.49 & 15.47 & 13.34 & 11.44 & 19.14 & 14.54 & 16.61 & 6.61 & 13.22 & 13.85 \\
\hline CEC (KTK) & $\mathrm{cmolkg}$ & 52.42 & 45.89 & 50.01 & 48.79 & 46.66 & 48.45 & 59.13 & 46.49 & 45.62 & 42.25 & 51.41 & 49.86 \\
\hline Total Pb & $\mathrm{ppm}$ & 5.19 & 2.25 & 5.36 & 4.38 & 1.13 & 0.68 & 2.03 & 2.24 & 1.15 & 0.93 & 1.54 & 2.60 \\
\hline Total Cd & ppm & 0.27 & $<0.20$ & 0.40 & 0.28 & $<0.20$ & 0.21 & 0.41 & 0.38 & 0.22 & 0.25 & 0.28 & 0.33 \\
\hline
\end{tabular}

Sumber: Laboratorium Central Plantation Services PT. Central Alam Resources Lestari, tanggal 15 Februari 2019

Secara umum, tanah gambut terbakar dengan aplikasi perlakuan kompos alang-alang memiliki tingkat dekomposisi yang lebih lanjut daripada tanah gambut yang tidak diberi perlakuan kompos alang-alang. Hal ini berkaitan dengan bahan organik dari kompos alang-alang yang lebih mudah terdekomposisi oleh mikroorganisme tanah.

Aplikasi kompos alang - alang pada tanah gambut terbakar tidak berpengaruh pada ketersediaan logam berat $\mathrm{Pb}$ dan $\mathrm{Cd}$. Pada tabel terlihat tanah gambut terbakar sebelum dan sesudah aplikasi perlakuan memperlihatkan nilai yang hampir sama, secara keseluruhan nilai tersebut masih dalam batas normal kandungan logam berat tanah.

\section{Tinggi Tanaman $(\mathrm{cm})$}

Analisis Ragam menunjukkan bahwa secara interaksi perlakuan tanah gambut terbakar (G) dan aplikasi kompos alang - alang (K) tidak memberikan pengaruh nyata, sedangkan secara utama aplikasi perlakuan kompos alang - alang memberikan pengaruh nyata dan perlakuan tanah gambut terbakar tidak memberikan pengaruh nyata terhadap tinggi tanaman kacang hijau. Rerata hasil jumlah tinggi tanaman kacang hijau setelah dilakukan uji lanjut Beda Nyata Jujur (BNJ) pada taraf $5 \%$ dapat dilihat pada Tabel 4 .

Berdasarkan data Tabel 4 dapat disimpulkan bahwa pengaruh utama aplikasi perlakuan kompos alang - alang memberikan pengaruh nyata terhadap tinggi tanaman kacang hijau dimulai pada umur 14 hst sampai dengan 35 hst. Pengaruh utama aplikasi perlakuan kompos alang - alang untuk parameter tinggi tanaman pada umur $35 \mathrm{hst}$ menunjukkan nilai tertinggi pada perlakuan K3 (375 g/polybag) yaitu $52.25 \mathrm{~cm}$, keadaan ini menunjukkan bahwa tinggi tanaman kacang hijau masih berada di bawah rentang tinggi tanaman yang terdapat pada deskripsi tanaman kacang hijau Varietas Kutilang yaitu 53 - 60 cm. Aplikasi perlakuan K3 (375 g/polybag) berbeda nyata terhadap perlakuan 250 g/polybag (K2), $125 \mathrm{~g} /$ polybag (K1) dan tanpa aplikasi kompos alang - alang (K0) dengan rerata $43.91 \mathrm{~cm}, 29.16 \mathrm{~cm}$ dan $26.10 \mathrm{~cm}$, hal ini berarti pengaruh utama aplikasi kompos alang - alang belum mampu meningkatkan tinggi tanaman dan pertumbuhan kacang hijau melebihi pertumbuhan yang optimal.

Menurut Setyati (1979), tinggi tanaman merupakan indikator pertumbuhan tanaman. Pertambahan tinggi tanaman merupakan salah satu bentuk adanya peningkatan pembelahan dan pembesaran sel dari hasil peningkatan fotosintat tanaman. Peningkatan tinggi tanaman merupakan hasil proses pembelahan, perpanjangan dan pembesaran sel.

Selanjutnya Campbell (1999), menyatakan bahwa pertumbuhan tanaman didefinisikan sebagai proses kenaikan volume bersifat irreversibel (tidak dapat balik) dan terjadi karena adanya pertambahan jumlah sel dan pembesaran tiap - tiap sel. Pada proses pertumbuhan disertai dengan terjadinya 
perubahan bentuk. Pada beberapa jaringan pembesaran sel sama pada segala arah disebut dengan isodiametris. Proses perpanjangan tunas terjadi melalui pertumbuhan ruas sedikit lebih tua di bawah ujung tunas tersebut.
Pertumbuhan ini disebabkan pembelahan sel dan pemanjangan sel dalam ruas. Pembelahan sel dan pertumbuhan yang terus menerus sehingga mendorong ke arah pemanjangan batang dan ruas.

Tabel 4. Rerata Tinggi Tanaman Kacang Hijau pada Tanah Gambut Terbakar dengan aplikasi Kompos Alang-Alang (cm)

\begin{tabular}{|c|c|c|c|c|c|c|}
\hline \multirow{2}{*}{ HST } & \multirow{2}{*}{$\begin{array}{c}\text { Perlakuan } \\
\text { Tanah Gambut } \\
\text { Terbakar (G) } \\
\end{array}$} & \multicolumn{4}{|c|}{ Aplikasi Kompos Alang - Alang (K) } & \multirow{2}{*}{ Rerata $(\mathrm{G})$} \\
\hline & & $\mathrm{K} 0(0 \mathrm{~g})$ & K1 $(125 \mathrm{~g})$ & $\mathrm{K} 2(250 \mathrm{~g})$ & K3 $(375 \mathrm{~g})$ & \\
\hline \multirow{3}{*}{14} & $\mathrm{G} 1(0-25 \mathrm{~cm})$ & 18.48 & 17.21 & 20.13 & 23.21 & 19.76 \\
\hline & $\mathrm{G} 2(25-50 \mathrm{~cm})$ & 17.22 & 17.46 & 22.33 & 23.09 & 20.03 \\
\hline & $\mathrm{G} 3(50-75 \mathrm{~cm})$ & 17.69 & 17.36 & 20.42 & 19.61 & 18.77 \\
\hline & Rerata $(\mathrm{K})$ & $17.34 \mathrm{~b}$ & $17.80 \mathrm{~b}$ & $20.96 \mathrm{a}$ & $21.97 \mathrm{a}$ & \\
\hline & $\mathrm{KK}=12.47 \%$ & \multicolumn{2}{|c|}{$\mathrm{BNJ} G=2.48$} & \multicolumn{2}{|c|}{$\mathrm{BNJ} \mathrm{K}=3.16$} & \\
\hline \multirow{3}{*}{21} & $\mathrm{G} 1(0-25 \mathrm{~cm})$ & $22.91 \mathrm{bc}$ & $21.76 \mathrm{c}$ & $28.21 \mathrm{abc}$ & $31.78 \mathrm{ab}$ & 26.16 \\
\hline & $\mathrm{G} 2(25-50 \mathrm{~cm})$ & $19.46 \mathrm{c}$ & $21.52 \mathrm{c}$ & $31.37 \mathrm{ab}$ & $32.86 \mathrm{a}$ & 26.30 \\
\hline & $\mathrm{G} 3(50-75 \mathrm{~cm})$ & $20.77 \mathrm{c}$ & $21.40 \mathrm{c}$ & $26.52 \mathrm{abc}$ & $26.00 \mathrm{abc}$ & 23.67 \\
\hline & Rerata $(\mathrm{K})$ & $21.04 \mathrm{~b}$ & $21.56 \mathrm{~b}$ & $28.70 \mathrm{a}$ & $30.21 \mathrm{a}$ & \\
\hline & $\mathrm{KK}=12.69 \%$ & \multicolumn{2}{|c|}{$\mathrm{BNJ} \mathrm{G}=3.28$} & \multicolumn{2}{|c|}{ BNJ K $=4.19$} & \\
\hline \multirow{5}{*}{28} & $\mathrm{G} 1(0-25 \mathrm{~cm})$ & $26.16 \mathrm{bc}$ & $26.29 \mathrm{bc}$ & $34.73 \mathrm{ab}$ & $41.39 \mathrm{a}$ & 32.14 \\
\hline & $\mathrm{G} 2(25-50 \mathrm{~cm})$ & $21.66 \mathrm{c}$ & $26.28 \mathrm{bc}$ & $39.88 \mathrm{a}$ & $42.76 \mathrm{a}$ & 32.64 \\
\hline & $\mathrm{G} 3(50-75 \mathrm{~cm})$ & $23.57 \mathrm{bc}$ & $25.36 \mathrm{bc}$ & $33.43 \mathrm{ab}$ & $33.49 \mathrm{ab}$ & 28.96 \\
\hline & Rerata $(\mathrm{K})$ & $23.79 \mathrm{~b}$ & $25.97 \mathrm{~b}$ & $36.01 \mathrm{a}$ & $39.21 \mathrm{a}$ & \\
\hline & $\mathrm{KK}=12.28 \%$ & \multicolumn{2}{|c|}{ BNJ G $=3.91$} & \multicolumn{2}{|c|}{ BNJ K $=4.99$} & \\
\hline \multirow{5}{*}{35} & $\mathrm{G} 1(0-25 \mathrm{~cm})$ & $28.67 \mathrm{de}$ & $30.11 \mathrm{cde}$ & $41.79 \mathrm{bcd}$ & $54.40 \mathrm{ab}$ & 38.74 \\
\hline & $\mathrm{G} 2(25-50 \mathrm{~cm})$ & $22.92 \mathrm{e}$ & 29.17 cde & $47.00 \mathrm{ab}$ & $56.40 \mathrm{a}$ & 38.87 \\
\hline & $\mathrm{G} 3(50-75 \mathrm{~cm})$ & $26.71 \mathrm{e}$ & $28.20 \mathrm{de}$ & $42.93 \mathrm{abc}$ & $45.94 \mathrm{ab}$ & 35.95 \\
\hline & Rerata $(\mathrm{K})$ & $26.10 \mathrm{c}$ & $29.16 \mathrm{c}$ & $43.91 \mathrm{~b}$ & $52.25 \mathrm{a}$ & \\
\hline & $\mathrm{KK}=12.79 \%$ & \multicolumn{2}{|c|}{ BNJ G $=4.94$} & $\mathrm{BNJ}$ & $=6.30$ & \\
\hline
\end{tabular}

Angka-angka pada baris dan kolom yang diikuti huruf kecil yang sama menunjukkan tidak berbeda nyata menurut uji lanjut Beda Nyata Jujur (BNJ) pada taraf $5 \%$.

Data pada Tabel 4 menunjukkan bahwa interaksi perlakuan tanah gambut terbakar dan kompos alang - alang serta pengaruh utama perlakuan tanah gambut terbakar pada masing - masing kedalaman tidak berpengaruh nyata terhadap tinggi tanaman kacang hijau pada umur 14 hst, akan tetapi aplikasi kompos alang - alang sebanyak 375 g/polybag (K3) memberikan pengaruh nyata terhadap tinggi tanaman kacang hijau serta berbeda nyata terhadap perlakuan 125 g/polybag (K1) dan tanpa kompos alang alang (K0). Adapun rerata tinggi tanaman tertinggi yaitu $23.21 \mathrm{~cm}$ diperoleh pada perlakuan G1K3, dimana tanaman kacang hijau ditanam pada tanah gambut terbakar kedalaman $0-25 \mathrm{~cm}$ dengan aplikasi kompos alang - alang sebanyak 375 g/polybag. Sedangkan perlakuan G1K1 menunjukkan tinggi tanaman terendah pada umur 14 hst yaitu $17.21 \mathrm{~cm}$.

Tabel 4 juga menunjukkan bahwa secara interaksi dan secara utama aplikasi kompos alang - alang sebanyak 375 g/polybag memberikan pengaruh nyata terhadap tinggi tanaman kacang hijau pada umur 21 hst, sedangkan Tanah Gambut Terbakar pada masing-masing kedalaman tidak berpengaruh nyata. Adapun rerata tinggi tanaman tertinggi yaitu $32.86 \mathrm{~cm}$ diperoleh pada perlakuan G2K3, dimana tanaman kacang hijau ditanam pada tanah gambut terbakar kedalaman $25-20$ $\mathrm{cm}$ dan diberi kompos alang - alang sebanyak 375 g/polybag. Sedangkan perlakuan G2K0 menunjukkan tinggi tanaman terendah pada umur 21 hst yaitu $19.46 \mathrm{~cm}$.

Data pada Tabel 4 memperlihatkan bahwa secara interaksi dan secara utama 
aplikasi kompos alang - alang sebanyak 375 g/polybag memberikan pengaruh nyata terhadap tinggi tanaman kacang hijau pada umur 28 hst, sedangkan Tanah Gambut Terbakar pada masing-masing kedalaman tidak berpengaruh nyata. Adapun rerata tinggi tanaman tertinggi yaitu $42.76 \mathrm{~cm}$ diperoleh pada perlakuan G2K3, dimana tanaman kacang hijau ditanam pada tanah gambut terbakar kedalaman $25-20 \mathrm{~cm}$ dengan aplikasi kompos alang - alang sebanyak 375 g/polybag. Sedangkan perlakuan G2K0 menunjukkan tinggi tanaman terendah pada umur 28 hst yaitu $21.66 \mathrm{~cm}$.

Pada tanaman kacang hijau umur 35 hst terlihat bahwa interaksi tanah gambut terbakar dan kompos alang - alang serta pengaruh utama kompos alang - alang memberikan pengaruh nyata, sedangkan pengaruh utama tanah gambut terbakar pada masing-masing kedalaman tidak berpengaruh nyata terhadap tinggi tanaman kacang hijau. Rerata tinggi tanaman kacang hijau tertinggi yaitu $56.40 \mathrm{~cm}$ diperoleh pada perlakuan G2K3, dimana tanaman kacang hijau ditanam pada tanah gambut terbakar kedalaman $25-20$ cm dengan aplikasi kompos alang - alang sebanyak $375 \mathrm{~g} /$ polybag dan berbeda nyata terhadap interaksi perlakuan G1K2, G1K1, G2K1, G1K0, G3K1, G2K0 dan G3K0, dan hal ini menunjukkan bahwa tinggi tanaman kacang hijau berada di rentang tinggi tanaman yang terdapat pada deskripsi tanaman kacang hijau Varietas Kutilang yaitu $53-60 \mathrm{~cm}$. Sedangkan perlakuan G2K0 menunjukkan tinggi tanaman terendah pada umur 35 hst yaitu $22.92 \mathrm{~cm}$.

Pertumbuhan tinggi tanaman akan optimal apabila tanaman dapat mensuplai unsur hara dengan baik ke seluruh bagian tanaman. Jika unsur hara yang dibawa akar sedikit maka akan menghambat pertumbuhan dan perkembangan tanaman, hal ini terjadi pada tanah gambut terbakar yang mengandung asam - asam fenolat (Hartatik et al., 2004). Beberapa hasil penelitian menunjukkan bahwa asam-asam fenolat bersifat fitotoksik bagi tanaman dan menyebabkan pertumbuhan tanaman terhambat (Driessen, 1978; Stevenson, 1994; Tsutsuki, 1984). Asam asam fenolat tersebut berpengaruh menghambat perkembangan akar tanaman dan penyediaan hara di dalam tanah (Hartatik et al., 2004).

\section{Berat Kering Biji Per Tanaman (g)}

Hasil pengamatan berat kering biji per tanaman kacang hijau setelah dilakukan analisis ragam, menunjukkan bahwa secara interaksi maupun pengaruh utama tanah gambut terbakar dan aplikasi kompos alang - alang berpengaruh nyata terhadap berat kering biji per tanaman kacang hijau. Rerata jumlah berat kering biji per tanaman kacang hijau setelah diuji lanjut BNJ pada taraf $5 \%$ dapat dilihat pada Tabel 5.

Data yang ditampilkan pada Tabel 5 merupakan hasil dari Transformasi Akar, karena data asli berat kering biji tanaman kacang hijau yang diperoleh dari penelitian ini memiliki Koefisien Keragaman (KK) yang besar.

Pada Tabel 5 menunjukkan bahwa secara interaksi perlakuan aplikasi kompos alang - alang $375 \mathrm{~g} /$ polybag pada tanah gambut terbakar kedalaman $0-25 \mathrm{~cm}(\mathrm{G} 1 \mathrm{~K} 3)$ berbeda nyata terhadap perlakuan G1K2, G2K1, G3K0, G3K1, G2K0, dan G1K0, dimana berat kering biji tertinggi diperoleh pada interaksi perlakuan G1K3 yaitu $5.98 \mathrm{~g}$. Hal ini dapat disebabkan karena adaptasi tanaman kacang hijau yang ditanam pada tanah gambut terbakar kedalaman $0-25 \mathrm{~cm}$ dan diaplikasikan kompos alang - alang sebanyak $375 \mathrm{~g} /$ polybag - lebih baik, sehingga mampu menghasilkan berat kering biji tanaman yang lebih baik. Berat kering biji yang terendah diperoleh pada interaksi perlakuan G1K0 (tanpa aplikasi kompos alang - alang) yaitu $0.54 \mathrm{~g}$, hal ini diduga karena tanpa aplikasi perlakuan kompos alang - alang tidak mendapatkan asupan nutrisi dengan baik sehingga mempengaruhi berat kering biji tanaman kacang hijau varietas kutilang dengan rata - rata hasil 1.13 ton/ha.

Secara utama pengaruh pemberian kompos alang - alang berpengaruh nyata terhadap berat kering biji tanaman kacang hijau, adapun berat kering biji tanaman tertinggi diperoleh pada perlakuan aplikasi kompos alang - alang $375 \mathrm{~g} /$ polybag dengan berat kering biji $5.79 \mathrm{~g}$. Perlakuan ini berbeda nyata terhadap perlakuan aplikasi kompos alang - alang lainnya yaitu $0 \mathrm{~g} /$ polybag, 125 g/polybag dan $250 \mathrm{~g} /$ polybag dengan berat kering biji masing - masing $1.54 \mathrm{~g}, 2.61 \mathrm{~g}$ dan $4.72 \mathrm{~g}$. 
Tabel 5. Rerata Berat Kering Biji per Tanaman Kacang Hijau pada Tanah Gambut Terbakar dengan aplikasi Kompos Alang-Alang (g)

\begin{tabular}{|c|c|c|c|c|c|}
\hline \multirow{2}{*}{$\begin{array}{c}\text { Perlakuan } \\
\text { Tanah Gambut Terbakar } \\
(\mathrm{G})\end{array}$} & \multicolumn{4}{|c|}{ Aplikasi Kompos Alang - Alang (K) } & \multirow{2}{*}{ Rerata } \\
\hline & $\mathrm{K} 0(0 \mathrm{~g})$ & $\mathrm{K} 1(125 \mathrm{~g})$ & $\mathrm{K} 2(250 \mathrm{~g})$ & $\mathrm{K} 3(375 \mathrm{~g})$ & \\
\hline $\mathrm{G} 1(0-25 \mathrm{~cm})$ & $0.54 \mathrm{f}$ & $2.77 \mathrm{de}$ & $3.97 \mathrm{bcd}$ & $5.98 \mathrm{a}$ & 3.32 \\
\hline $\mathrm{G} 2(25-50 \mathrm{~cm})$ & $1.75 \mathrm{ef}$ & 3.05 cde & $5.41 \mathrm{ab}$ & $5.52 \mathrm{ab}$ & 3.93 \\
\hline $\mathrm{G} 3(50-75 \mathrm{~cm})$ & $2.34 \mathrm{def}$ & $2.01 \mathrm{ef}$ & $4.80 \mathrm{abc}$ & $5.87 \mathrm{ab}$ & 3.75 \\
\hline Rerata & $1.54 \mathrm{~d}$ & $2.61 \mathrm{c}$ & $4.72 \mathrm{~b}$ & $5.79 \mathrm{a}$ & \\
\hline
\end{tabular}

Angka-angka pada baris dan kolom yang diikuti huruf kecil yang sama menunjukkan tidak berbeda nyata menurut uji lanjut Beda Nyata Jujur (BNJ) pada taraf $5 \%$.

Pada penelitian ini diduga bahwa pengaruh utama aplikasi kompos alang - alang pada tanah gambut terbakar diantaranya mampu memenuhi kebutuhan hara tanaman kacang hijau dalam proses pengisian biji, hal ini terlihat dari interaksi aplikasi perlakuan kompos alang - alang 375 g/polybag pada tanah gambut terbakar kedalaman $0-25 \mathrm{~cm}$ (G1K3) mampu menghasilkan berat kering biji tertinggi. Agustina (2004) dalam Sulianto (2018) menyatakan bahwa proses pengisian biji pada tanaman sangat ditentukan oleh tingkat pemenuhan hara dan proses fotosintesis tanaman, unsur hara yang dibutuhkan tersebut akan saling berkaitan dalam meningkatkan proses fotosintesis tanaman, unsur hara tersebut diantaranya yaitu $\mathrm{N}, \mathrm{P}, \mathrm{K}, \mathrm{Ca}$, dan $\mathrm{Mg}$.

\section{KESIMPULAN DAN SARAN}

\section{Kesimpulan}

1. Aplikasi kompos alang - alang pada tanah gambut terbakar mampu memperbaiki sifat

kimia tanah berupa peningkatan C-Organik pH, N-total, P2O5, K-dd, Mg-dd, Ca-dd, KTK dan menurunkan C/N Ratio, Al-dd, Total $\mathrm{Pb}$. Hasil terbaik diperoleh dengan mengaplikasikan kompos alang - alang 375 g/polybag pada tanah gambut terbakar kedalaman $0-25 \mathrm{~cm}$.

2. Interaksi Perlakuan tanah gambut terbakar dan aplikasi kompos alang - alang memberikan pengaruh nyata terhadap parameter tinggi tanaman dan berat kering biji per tanaman dengan perlakuan terbaik aplikasi kompos alang - alang 375 g/polybag pada tanah gambut terbakar kedalaman $25-50 \mathrm{~cm}$.

3. Pengaruh utama aplikasi kompos alang alang memberikan pengaruh nyata terhadap terhadap parameter tinggi tanaman dan berat kering biji per tanaman perlakuan terbaik adalah aplikasi kompos alang alang $375 \mathrm{~g} /$ polybag.

\section{Saran}

Aplikasi kompos alang - alang 375 g/polybag pada tanah gambut terbakar kedalaman $0-25,25-50$ dan $50-75 \mathrm{~cm}$ berpotensi untuk budidaya tanaman kacang hijau, meskipun belum maksimal dalam memperbaiki sifat kimia tanah gambut terbakar itu sendiri dan untuk itu disarankan hal - hal sebagai berikut :

1. Mengingat penelitian ini menggunakan tanah gambut terbakar 3 (tiga) tahun setelah kebakaran lahan gambut, maka untuk memperoleh pengaruh yang nyata, penelitian pada tanah gambut terbakar sebaiknya dilaksanakan segera setelah lahan gambut terbakar.

2. Sebaiknya diadakan penelitian lanjutan dengan mengaplikasikan beberapa amelioran sebagai pembanding.

3. Tidak menggunakan kedalaman tanah gambut terbakar sebagai faktor perlakuan.

4. Penggunaan teknologi yang tepat agar dapat memperbaiki sifat kimia tanah gambut terbakar yang miskin hara, sehingga pengelolaan lahan gambut terbakar sebagai lahan budidaya tanaman kacang hijau menjadi lebih efektif, efisien dan berkelanjutan.

\section{DAFTAR PUSTAKA}

Anshari, G. Z. 2010. A Preliminary Assessment of Peat Degradation in West Kalimantan. Biogeosciences Discuss. 7: 3503-3520.

Arief, A. dan Irman. 1996. Ameliorasi lahan kering masam untuk tanaman pangan, dalam : Kinerja Penelitian Tanaman Pangan. Buku 6 : Prosiding Simposium 
Penelitian Tanaman Pangan III. Jakarta/Bogor, 23-25 Agustus 1996. Hal : 1687 - 1697.

Balai Penelitian Tanah. 2009. Petunjuk Teknis Analisis Kimia Tanah, Tanaman, Air, dan Pupuk. Balai Penelitian Tanah, Badan Penelitian dan Pengembangan Pertanian, Departemen Pertanian. Bogor.

Campbell, N. A., J. B. Reece and L. E. Mitchell. 1999. Biologi. Erlangga. Jakarta.

Dikici, H. dan H. Yilmaz. 2006. Peat Fire Effects on Some Properties of an Artificially Drained Peatland. Journal Environ. Qual. 35: 866-870.

Driessen, P. M. 1978. Peat soils. Pp 763-779. In IRRI. Soil and Rice. Los Banos. Philippines.

Hartatik, W., Subiksa. I. G. M., dan A. Dariah. 2004. Sifat Kimia dan Fisik Tanah Gambut. Diterbitkan pada Buku Pengelolaan Lahan Gambut Berkelanjutan. Balai Besar Litbang Sumberdaya Lahan Pertanian. Badan Penelitian dan Pengembangan Pertanian. Kementrian Pertanian. 2011. Hal. 45-56.

Kementerian Pertanian Republik Indonesia. 2019. Data Lima Tahun Terakhir. www.pertanian.go.id, diakses Oktober 2019.

Lubis, Abdul Hadi. 2016. Respon Karakteristik Tanah Gambut terhadap Kebakaran. Skripsi Sarjana. Departemen Silvikultur Fakultas Kehutanan Institut Pertanian Bogor. Bogor.

Maharani, T. 2002. Pengaruh Pemberian Bokashi dan Kompos Alang-alang Terhadap Beberapa Sifat Kimia Tanah Podzolik Merah Kuning dan Pertumbuhan serta Produksi Tanaman Jagung (Zea mays L.). Skripsi Sarjana. Jurusan Agronomi, Fakultas Pertanian. Universitas Riau. Pekanbaru.
Mintari, Dwi Astiani dan Togar Fernando Manurung. 2019. Beberapa Sifat Fisik dan Kimia Tanah Gambut Terbakar dan Tidak Terbakar di Desa Sungai Besar Kabupaten Ketapang. Fakultas Kehutanan Universitas Tanjungpura. Jurnal Hutan Lestari (2019) 7(2) : 947 $-955$.

Riadi, Munal; Nelvia dan Islan. 2015. Aplikasi Kompos Yang Diperkaya Dengan Berbagai Bahan Untuk Tanaman Kedelai (Glycine max L. Merril) Diantara Tanaman Sawit Muda Di Lahan Gambut. Jurusan Agroteknologi Fakultas Pertanian Universitas Riau. Jom Faperta 2(1), Februari 2015.

Setyati. 1979. Pengantar Agronomi. Yasaguna. Jakarta.

Stevenson, F. J. 1994. Humus Chemistry, Genesis, Composition, Reactions. John Wileydan Sons, New York.

Sulianto, A. 2018. Pengaruh Pemberian Fly Ash dan Legin Terhadap Pertumbuhan dan Produksi Tanaman Kacang Kedelai (Glycine max. L). Skripsi. Fakultas Pertanian Universitas Islam Riau.

Sutriana, S. dan Raisa Baharuddin. 2017. Uji Tingkat Kematangan Kompos Terhadap Pertumbuhan dan Produksi Tiga Varietas Bawang Merah (Allium ascolanicum) Pada Tanah Gambut. Laporan Tahun Terakhir Penelitian Dosen Pemula. Universitas Islam Riau. Pekanbaru.

Tsutsuki, K. 1984. Volatile products and lowmolecular-weight phenolic products of the anaerobic decomposition of organic matter. In Organic matter and rice. IRRI. Philippines.

Wahyunto dan B. Heryanto. 2005. Sebaran Gambut dan Status Terkini di Sumatera, dalam CCFPI. 2005. Pemanfaatan Lahan Gambut Secara Bijaksana untuk Manfaat Berkelanjutan. Prosiding Lokakarya. Indonesia Programe. Bogor. 